\title{
Leaf development of native bluestem grasses in relation to degree-day accumulation
}

\author{
ROBERT L. GILLEN AND ANNE L. EWING
}

Authors are associate professor, Agronomy Department, and adjunct assistant professor, Botany Department, Oklahoma State University, Stillwater 74078.

\section{Abstract}

Degree-day accumulation is commonly used to predict crop development and harvest dates. Relationships between degree-day accumulation and phenological development of range forage grasses have received less attention. This research tested the hypotheses that leaf development by big bluestem [Andropogon gerardii Vitman] and little bluestem [Schizachyrium scoparium (Michx.) Nash] is related to degree-day accumulation and that these relationships are stable over environments and years within environments. Study environments included native prairie, a spaceplanted garden, and a growth chamber. Individual tillers of big and little bluestem were permanently marked and fully developed leaves were counted once or twice weekly over 3 growing seasons and 1 growth chamber trial. Quadratic regression models accounted for 94 to $99 \%$ of the observed variation in leaf development for all species-environment-year combinations. Regression models were significantly different $(p=0.05)$ among environments and between years within environments. Lack of model stability over years was a result of high variation in total leaves produced per tiller relative to annual variation in degree-day accumulation. The simple independent variable, day of year, predicted leaf development equally as well as degree-day accumulation.

Key Words: growing degree-days, temperature, phenology, morphological development, Andropogon gerardit Vitman, Schizachyrium scoparium (Michx.) Nash

Temperature plays an important role in governing the rate of plant development. Degree-day accumulation has long been used to predict the initiation of plant growth in the spring or the onset of flowering (Wang 1960). In agriculture, temperature indices have been used to predict crop development, classify species and hybrids as to maturity date, and evaluate climates for crop suitability (Russelle et al. 1984).

Research on temperature effects on the growth and development of grasses has concentrated on cultivated crop species while little emphasis has been placed on range forage grasses. In the northern Great Plains, phenological development of grasses is strongly related to degree-day accumulation but, within species, does not appear to be affected by soil moisture, soil fertility, or grazing intensity (Frank et al. 1985, Frank and Hofmann 1989, Frank and Ries 1990). Temperature indices have also been used to predict forage yields when soil moisture is not limiting (George et al. 1988). Further development of temperature-plant phenology relationships would be useful in refining grazing management under intensive conditions when livestock movement is dependent on the rate of plant growth and would also be valuable in constructing forage production models.

\footnotetext{
The authors thank Joe Brummer, Russ Wright, DeAnn Lowder, Dwayne Rice, John Altom, Lisa McMurphy, and Holger Jensen for assistance in data collection.

Published with approval of the Director, Oklahoma Agricultural Experiment Station, as JA-5920.

Manuscript accepted 22 July 1991.
}

This research tested 2 hypotheses. First, leaf development of big bluestem [Andropogon gerardii Vitman] and little bluestem [Schizachyrium scoparium (Michx.) Nash], 2 dominant species of the tallgrass prairie, is related to degree-day accumulation. Second, the relationship between leaf development and degree-day accumulation is relatively constant among environments and years within environments.

\section{Study Area and Methods}

The study was conducted in 3 different environments including 2 field sites and a growth chamber. Both field sites were on the Oklahoma State University Stillwater Research Station, Stillwater, Okla. $\left(36^{\circ} \mathrm{N}, 97^{\circ} \mathrm{W}\right.$ ). The climate is continental with an average frost-free growing period of 204 days extending from April to October. Average precipitation is $831 \mathrm{~mm}$ with $65 \%$ falling as rain from May to October. Mean temperature is $15^{\circ} \mathrm{C}$ with average minimum and maximum temperatures ranging from $-4.3^{\circ} \mathrm{C}$ in January to $34^{\circ} \mathrm{C}$ in August (Myers 1982).

The first site was tallgrass prairie in high seral condition, dominated by little bluestem and big bluestem. The soil was a Renfrow silt loam (fine, mixed, thermic Udertic Paleustoll) classified as a Claypan Prairie range site. The second site was a space-planted garden containing big bluestem, little bluestem, and sideoats grama [Bouteloua curtipendula (Michx.) Torr.]. A repeating grid pattern was used for planting such that individuals of each species were surrounded by 3 individuals of 1 of the other species in a triangular pattern on $0.3-\mathrm{m}$ centers. The garden was planted 1 year prior to initiation of the experiment. Plant materials used in the garden were collected from native prairie approximately $10-\mathrm{km}$ southwest of the prairie site used in this study. The soil at the garden was a Norge loam (fine-silty, mixed, thermic Udic Paleustoll).

The growth chamber experiment was conducted in a Conviron Model PGW36 walk-in growth chamber. Growth conditions were 12 hour days and nights with $30^{\circ} \mathrm{C}-20^{\circ} \mathrm{C}$ day-night temperatures throughout the experiment. Light intensity was $225 \mu \mathrm{E} \mathrm{m}^{-2} \mathrm{~s}^{-1}$ at canopy level and was supplied by a mixture of incandescent and fluorescent sources. Experimental material consisted of plants of big and little bluestem propagated vegetatively from tillers or rhizomes or from seed collected from both the prairie and garden sites. Pots contained a mixture of peat, vermiculite, and sand (1:3:4 ratio) and were watered 3 times weekly throughout the study period. Pots were $15-\mathrm{cm}$ in diameter and $20-\mathrm{cm}$ tall.

Individual tillers of big and little bluestem were permanently marked with colored wire rings at the field sites in early to mid April as soon as emerging tillers could be positively identified by species. All tillers were on separate plants. Fifty tillers of each species were marked at each site in 1985 . Fifty tillers were also marked in the prairie in 1986 and 1987 , but sample size was reduced to 30 in the garden because tiller mortality during the measurement period was less at the garden site. Tiller height was measured twice weekly in 1985 and 1986 and once weekly in 1987. Sampling was 
terminated in mid to late July when inflorescences were exserted on $25 \%$ of the marked tillers. The number of fully developed leaves each tiller produced since growth initiation were counted at each sample date. Fully developed leaves were defined as leaves with a visible collar. Similar measurements were taken twice weekly in the growth chamber. Sample size in the growth chamber experiment ranged from 32 to 37 .

Degree-day accumulation was measured with an Omnidata Model TA-51-P Biophenometer housed in a standard slatted weather instrument shelter. Air temperature was sensed at 10minute intervals and an updated degree-day accumulation was calculated and stored electronically. A base temperature of $0^{\circ} \mathrm{C}$ was used for the calculations. Total degree-day accumulation (from the date of first tiller marking) was read each day tiller measurements were made.

Statistical analysis consisted of fitting quadratic regression models for each combination of species, environment, and year. Models were of the general form

$$
y=b_{0}+b_{1} * x+b_{2} * x^{2}
$$

where $y=$ predicted value of dependent variable, $x=$ value of independent variable, and $b_{0}, b_{1}, b_{2}=$ regression coefficients. The dependent variable was leaf number. Tiller means within sampling date were used as observations. Independent variables were degree-day accumulation and day of year. All models were standardized by starting the accumulations when 2 full leaves were present. Pair-wise comparisons of regression models were made for various treatment combinations using the methods of Neter and Wasserman (1974). Comparisons of major interest were between years within species and environment and between propagation methods within species in the growth chamber.

\section{Results}

\section{Environmental Conditions}

Precipitation was average to above average in 3 years of study (Table 1). Above-average total precipitation in 1985 and 1987 was

Table 1. Precipitation received at Stillwater, Okla., 1985-1987. Average is based on 87 years.

\begin{tabular}{|c|c|c|c|}
\hline Year & November-March & April-July & Total \\
\hline $1984-85$ & ${ }_{478}$ & $=-\mathrm{cm}=--$ & 881 \\
\hline $1985-86$ & 16.3 & 40.5 & $\begin{array}{l}00.1 \\
56.8\end{array}$ \\
\hline $1986-87$ & 43.0 & 43.8 & 86.8 \\
\hline Average & 20.2 & 38.4 & 58.6 \\
\hline
\end{tabular}

largely a result of above-average precipitation in the November-March period. Growing season precipitation was about average for the entire period. Variation in degree-day accumulation was not large over years (Fig. 1). Degree-day accumulation was most rapid in 1987 and least rapid in 1986.

\section{Regression Models}

Quadratic regressions were generally good descriptors of the observed data as typified by big bluestem at the prairie site in 1985 (Fig. 2). The regression models accounted for at least $94 \%$ of the observed variation in leaf number for all species-location-year combinations (Tables 2,3, and 4).

\section{Prairie Site}

There was little visual difference in growth responses between years for big bluestem at the prairie site (Fig. 3). Variability in growth response among years was greater for little bluestem as leaf production per tiller declined over years (Fig. 4). The reason for this decline is not known.

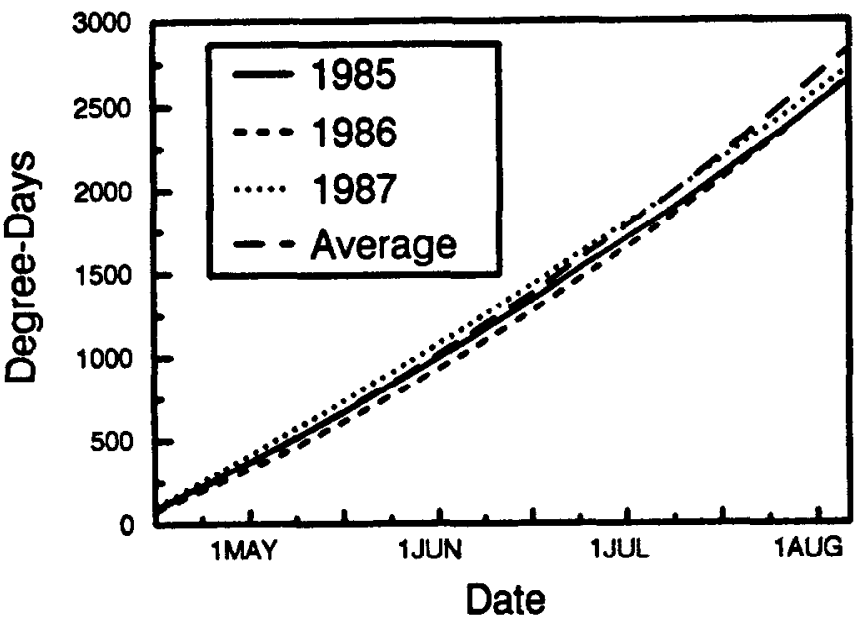

Fig. 1. Degree-day accumulation at Stillwater, Okla., 1985-87, and 87year average.

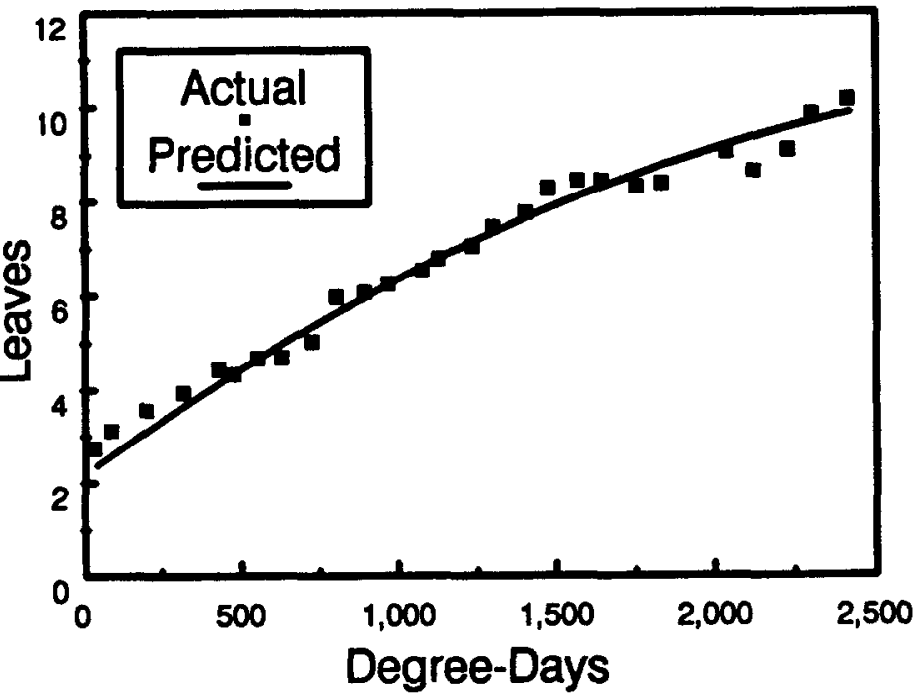

Fig. 2. Actual and predicted values for number of leaves per tiller for big bluestem at the prairie, Stillwater, Okla., 1985.

Table 2. Regression statisties for models relating leaf number and degreeday accumulation for big bluestem at 2 field sites.

\begin{tabular}{lcccccrr}
\hline \hline Location & Year & $\mathbf{N}$ & $\mathbf{R}^{2}$ & MSE $^{1}$ & $\mathbf{b}_{0}$ & $\begin{array}{c}\mathrm{b}_{1} \\
\left(10^{-3}\right)\end{array}$ & \multicolumn{1}{c}{$\begin{array}{c}\mathbf{b}_{2} \\
\left(10^{-7}\right)\end{array}$} \\
\hline Prairie & 1985 & 32 & 0.99 & 0.117 & $2.00^{2}$ & 4.95 & -7.12 \\
& 1986 & 31 & 0.99 & 0.050 & 2.00 & 5.40 & -10.54 \\
& 1987 & 14 & 0.98 & 0.133 & 2.00 & 4.21 & -5.85 \\
Garden & Pooled & 77 & 0.97 & 0.167 & 2.04 & 4.85 & -7.52 \\
& 1985 & 29 & 0.99 & 0.272 & 2.00 & 10.17 & -10.76 \\
& 1986 & 32 & 0.99 & 0.060 & 2.00 & 6.29 & -7.84 \\
& 1987 & 16 & 0.98 & 0.133 & 2.00 & 6.54 & -17.11 \\
& Pooled & 77 & $\mathbf{0 . 7 3}$ & $\mathbf{5 . 6 8 8}$ & 1.80 & $\mathbf{8 . 7 8}$ & -16.46 \\
\hline
\end{tabular}

1Mean square error of regression model.

2All regression coefficients are significant at $P=0.05$.

Regression models for all years were different from each other for both big and little bluestem $(p=0.05)$ and pooling the regression models over years was not appropriate. Regression coefficients and error variances both differed significantly among years. The pooled regression model still accounted for $97 \%$ of the observed variability for big bluestem (Table 2) and for practical purposes a pooled model might be acceptable for use.

\section{Garden Site}

Growth responses were not constant over years at the garden site. Leaf production per tiller declined dramatically from 1985 to 

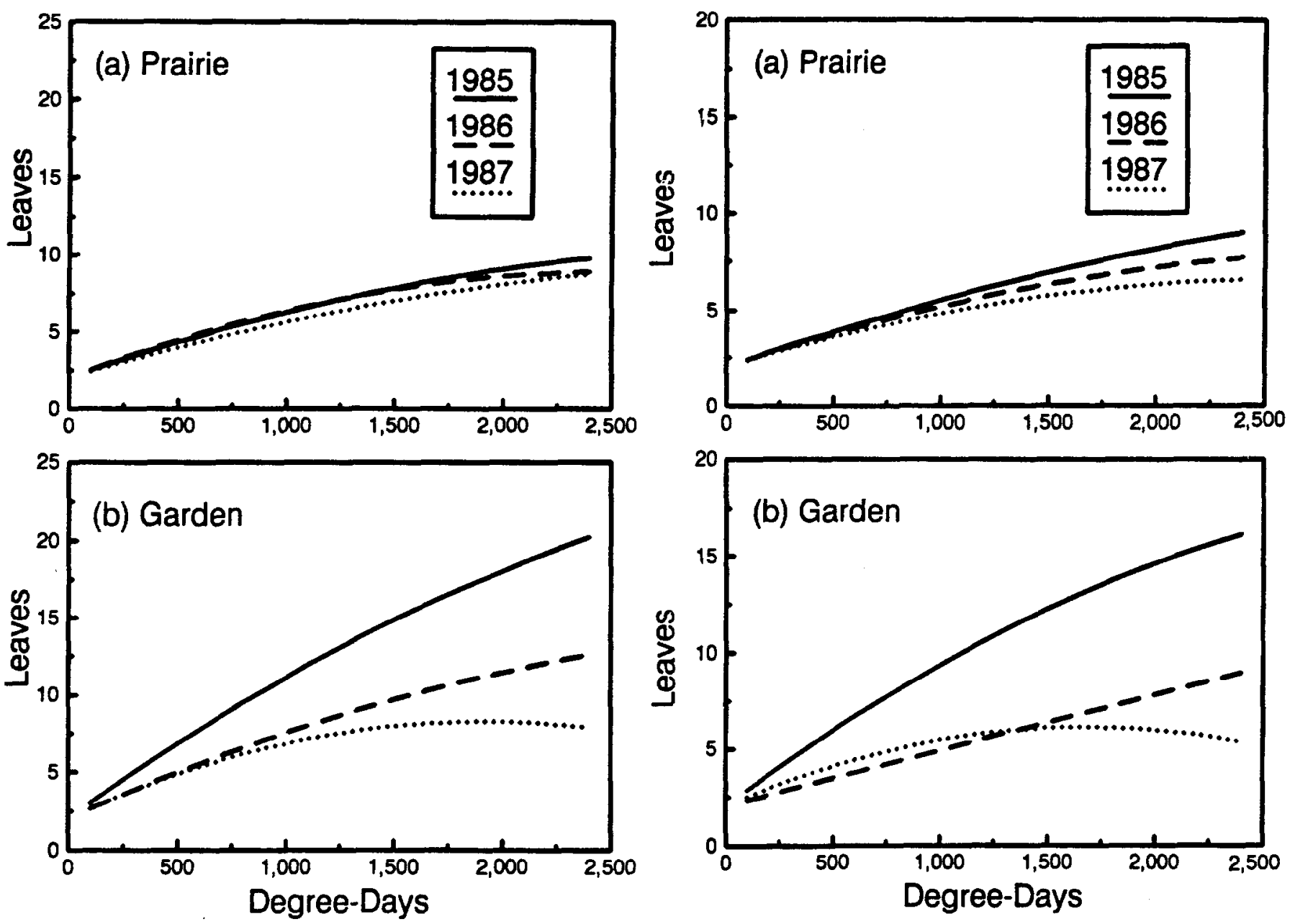

Fig. 3. Predicted values for number of leaves per tiller for big bluestem at (a) the prairie and (b) the garden, Stillwater, Okla., 1985-1987.

1987 for both species (Figs. 3 and 4). As with the prairie site, regression models were significantly different for all years. Pooled regression models accounted for only 73 and $51 \%$ of the observed variation for big and little bluestem, respectively, compared to 94 to $99 \%$ of the variation for individual years (Table 2 and 3). The recently established plants had clearly not reached equilibrium with their environment in the spaced planting. White (1985) reported that seeded grass stands often reach maximum production the second or third year after establishment and then produc-

Table 3. Regression statistics for models relating leaf number and degreeday accumulation for little bluestem at 2 field sites.

\begin{tabular}{lccccccc}
\hline \hline Location & Year & $\mathrm{N}$ & $\mathrm{R}^{2}$ & $\mathrm{MSE}^{1}$ & $\mathrm{~b}_{0}$ & $\begin{array}{c}\mathrm{b}_{1} \\
\left(10^{-3}\right)\end{array}$ & $\begin{array}{c}\mathrm{b}_{2} \\
\left(10^{-7}\right)\end{array}$ \\
\hline Prairie & 1985 & 33 & 0.98 & 0.103 & $2.00^{2}$ & 3.91 & -4.15 \\
& 1986 & 31 & 0.99 & 0.020 & 2.00 & 3.74 & -5.71 \\
& 1987 & 16 & 0.98 & 0.063 & 2.00 & 3.46 & -6.47 \\
& Pooled & 80 & 0.93 & 0.293 & 2.12 & 3.33 & -3.12 \\
Garden & 1985 & 29 & 0.98 & 0.343 & 2.00 & 8.39 & -10.47 \\
& 1986 & 31 & 0.98 & 0.097 & 2.00 & 2.90 & -14.66 \\
& 1987 & 15 & 0.94 & 0.101 & 2.00 & 4.91 & -14.60 \\
& Pooled & 75 & 0.51 & 6.242 & 1.62 & 6.88 & -14.50 \\
\hline
\end{tabular}

i Mean square error of regression model.

${ }_{2}^{A}$ All regression coefficients are significant at $P=0.05$ except for $b_{2}$ at the Garden site in 1986.

Fig. 4. Predicted values for number of leaves per tiller for little bluestem at (a) the prairie and (b) the garden, Stillwater, Okla., 1985-1987.

tion declines over the next 3 to 4 years.

The variability of leaf number per tiller was much greater over years than the variability in growing degree-day accumulation. The coefficient of variation over years for final leaf number was 12 and $21 \%$ for big and little bluestem at the prairie site and 41 and $48 \%$ for these 2 species at the garden site. In comparison, the coefficient of variation for degree-day accumulation at the termination of each year's data collection was only $1.4 \%$. This does not mean degreeday accumulation cannot be used to predict leaf appearance but small changes in degree-day accumulation would cause large changes in predicted leaf appearance. Degree-day accumulation was a more consistent predictor of flowering than of leaf appearance.

The use of day of year was as good a predictor of plant development as degree-day accumulation. The average amount of variation accounted for by the regression models for all specieslocation-year combinations was $\mathbf{9 8 \%}$ for both day of year and degree-day accumulation. Models using day of year as the independent variable also could not be pooled over years because error variances and regression coefficients were significantly different $(p$ $=0.05$ ). However, pooled models using day of year accounted for as much variance as pooled models using degree-day accumulation.

\section{Growth Chamber Experiment}

Leaf numbers of both species were much greater under controlled conditions than at the field sites (Figs. 5 and 6). Regression 

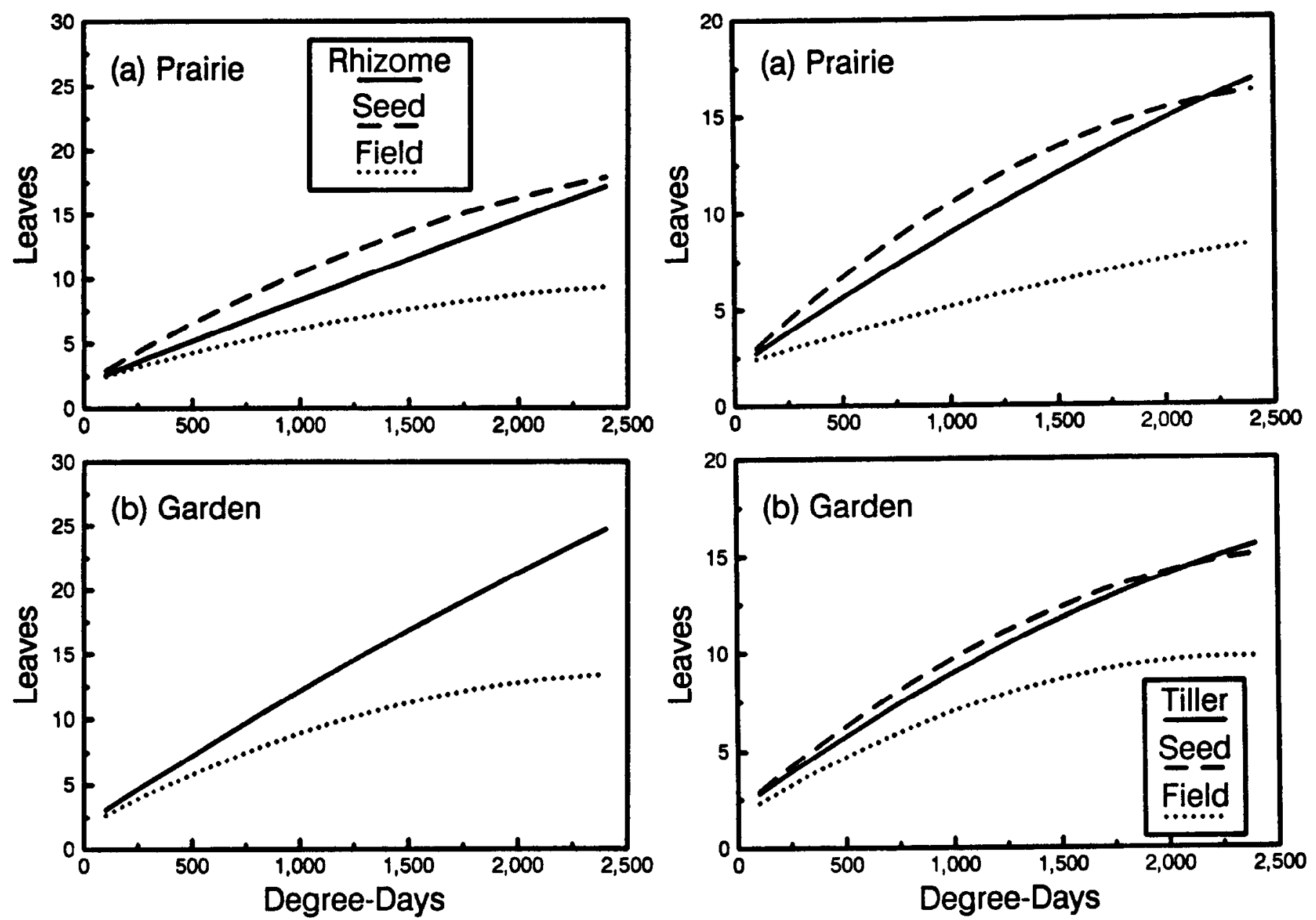

Fig. 5. Predicted values for number of leaves per tiller for big bluestem collected from (a) the prairie and (b) the garden when grown in the growth chamber. The curves marked field are the pooled regression models over years from the field.

coefficients and error variances both differed significantly $(P=$ 0.05 ) between sites and also between propagation methods for plant materials from the same site. Rate of leaf development was more rapid in the growth chamber than in the field. Higher total leaf production would be expected in the growth chamber than in the field sites because water was not limiting. It was not expected that leaf development would be more rapid in the growth chamber, at least not in the early stages of growth when soil water was adequate at the field sites. However, leaf development was more rapid in the growth chamber throughout the experiment. Plants

Fig. 6. Predicted values for number of leaves per tiller for little bluestem collected from (a) the prairie and (b) the garden when grown in the growth chamber. The curves marked field are the pooled regression models over years from the field site.

started from seed developed leaves slightly faster than plants started from vegetative materials in all 3 comparisons (Figs. 5 and 6). Growth chamber relationships may have little relevance to plants growing in resource-limited environments under competition with other plants. Extrapolation of growth chamber results to field environments was clearly unwarranted in this study.

\section{Discussion}

Degree-day accumulation was closely related to rate of leaf development of big and little bluestem. However, the relationship

Table 4. Regression statistics for models relating leaf number and degree-day accumulation in the growth chamber.

\begin{tabular}{|c|c|c|c|c|c|c|c|c|}
\hline Species & Source & & $\mathbf{N}$ & $\mathbf{R}^{2}$ & MSE' & $b_{0}$ & $\begin{array}{c}b_{1} \\
\left(10^{-3}\right)\end{array}$ & $\begin{array}{c}b_{2} \\
\left(10^{-7}\right)\end{array}$ \\
\hline \multirow[t]{2}{*}{ Big bluestem } & Prairie & $\begin{array}{l}\text { Rhizome } \\
\text { Seed }\end{array}$ & $\begin{array}{l}34 \\
37\end{array}$ & $\begin{array}{l}0.99 \\
0.99\end{array}$ & $\begin{array}{l}1.525 \\
0.270\end{array}$ & $\begin{array}{l}2.00^{2} \\
2.00\end{array}$ & $\begin{array}{l}6.38 \\
9.75\end{array}$ & $\begin{array}{r}-2.95 \\
-13.11\end{array}$ \\
\hline & Garden & Rhizome & 33 & 0.99 & 0.409 & 2.00 & 10.67 & -5.07 \\
\hline \multirow[t]{4}{*}{ Little bluestem } & Prairie & Tiller & 32 & 0.99 & 0.226 & 2.00 & 7.51 & -5.59 \\
\hline & & Seed & 35 & 0.97 & 0.552 & 2.00 & 10.32 & -18.34 \\
\hline & Garden & Tiller & 32 & 0.98 & 0.152 & 2.00 & 7.99 & -9.79 \\
\hline & & Seed & 35 & 0.98 & 0.371 & 2.00 & 9.36 & -16.31 \\
\hline
\end{tabular}

'Mean square error of regression model.

2All regression coefficients are significant at $P=0.05$. 
was inconsistent among years and environments, even though precipitation amounts were favorable during the study. Because degree-day accumulation varied relatively little over years, the number of leaves produced per tiller was the variable controlling the relationship from one year to the next. Frank et al. (1985) and Frank and Ries (1990) reported no differences in regression relationships over years and little or no change in leaf number between years. Frank and Ries (1990) also found varying soil moisture and fertility treatments did not affect the dependence of leaf development on degree-day accumulation. However, western wheatgrass (Agropyron smithii Rydb.) developed almost twice as rapidly in monoculture as when growing in a native grassland (Frank and Hofmann 1989). Davidson and Campbell (1983) and Bauer et al. (1984) both reported that moisture and fertility treatments did not alter the relationship between degree-day accumulation and leaf appearance for spring wheat. One important difference in these comparisons is that the genetic material in the previous studies (named varieties) was much more homogeneous than in this investigation. When genetic content was not as tightly controlled, yearto-year variability increased (Frank and Hofmann 1989).

Degree-day accumulation appeared to merely mark the passage of time. Using day of year as the independent variable simplified calculations but gave equally useful predictions. Other environmental variables such as soil water, plant competition, genetic composition, and grazing may be stronger determining factors in plant development than degree-day accumulation. More work will be required to quantify the affect of these variables before degreeday accumulation will be a useful predictor of plant development for big and little bluestem.

\section{Literature Cïted}

Bauer, A., A.B. Frank, and A.L. Black. 1984. Estimation of spring wheat leaf growth rates and anthesis from air temperature. Agron. J. 76:829-835.

Davidson, H.R., and C.A. Campbell. 1983. The effect of temperature, moisture and nitrogen on the rate of development of spring wheat as measured by degree days. Can. J. Plant Sci. 63:833-846.

Frank, A.B., J.D. Berdahl, and R.E. Barker. 1985. Morphological development and water use in clonal lines of four forage grasses. Crop Sci. 25:339-344.

Frank, A.B., and L. Hofmann. 1989. Relationship among grazing management, growing degree-days, and morphological development for native grasses on the Northern Great Plains. J. Range Manage. 42:199-202

Frank, A.B., and R.E. Ries. 1990. Effect of soil water, nitrogen, and growing degree-days on morphological development of crested and western wheatgrass. J. Range Manage. 43:257-260.

George, M.R., C.A. Raguse, W.J. Clawson, C.B. Wilson, R.L. Willoughby, N.K. McDougald, D.A. Duncan, and A.H. Murphy. 1988. Correlation of degree-days with annual herbage yields and livestock gains. J. Range Manage. 41:193-197.

Myers, H.R. 1982. Climatological data of Stillwater, Oklahoma 1893-1980. Oklahoma Agr. Exp. Sta. Res. Rep. P-821.

Neter, J., and W. Wasserman. 1974. Applied linear statistical models. Richard D. Irwin, Inc., Homewood, Ill.

Russelle, M.P., W.W. Wilhelm, R.A. Olson, and J.F. Power. 1984. Growth analysis based on degree days. Crop Sci. 24:28-32.

Wang, J.Y. 1960. A critique of the heat unit approach to plant response studies. Ecology 41:785-790.

White, L.M. 1985. Stand age, precipitation, and temperature effects on forage yield. J. Range Manage. 38:39-43. 